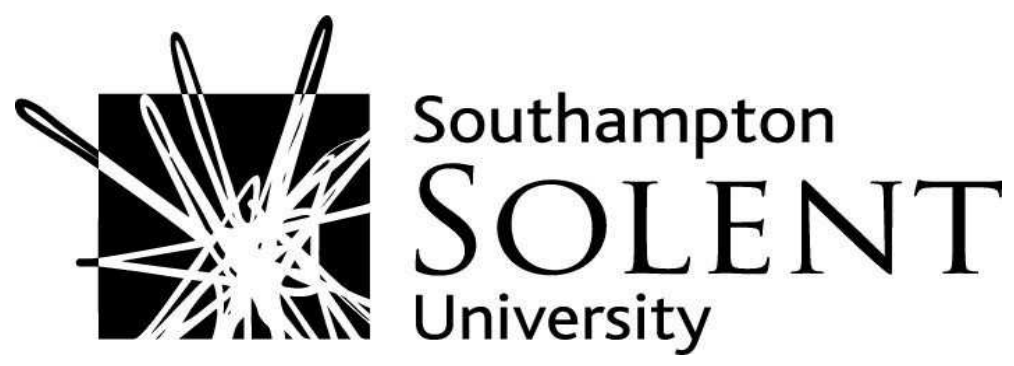

Jones, Robin. (2012). "Thinking" the domestic interior in post-colonial South Asia: the home of Geoffrey Bawa in Sri Lanka, 1960-1998. Interiors: design, architecture,culture, November 2012, 3 (3), pp. 203-226

Downloaded from http://ssudl.solent.ac.uk/2210/ 


\section{"Thinking" the Domestic Interior in Postcolonial South Asia: The Home of Geoffrey Bawa in Sri Lanka, 1960 to 1998}

\section{Robin D. Jones}

Robin Jones is Program Group Leader in the School of Visual Arts at Southampton Solent University. His doctoral research examined the material culture of colonial Sri Lanka using the methods of design history. His present research project investigates the negotiation of modernity and history in postcolonial South Asia through examination of the built environment, landscapes, and visual culture of postindependence Sri Lanka and India. robin.jones@solent.ac.uk
ABSTRACT This paper discusses the domestic interior of the architect Geoffrey Bawa at 33rd Lane, Colombo, Sri Lanka, created between c. 1960 and 1998. This interior will be assessed in relation to the intellectual technique of "bricolage," a term applied here to conceptualize the furnishing of the home as something that structures space, thereby making it meaningful. Previously, no sustained or critically engaged attempt has been made to assess his interior spaces as locations to "think" a way of living appropriate to the newly independent Ceylon/Sri Lanka. His later domestic interiors, such as his own home, combine "antique" colonial furniture with International Style furniture and contemporary Sri Lankan artworks. Through bricolage, Bawa

Reprints available directly from the publishers

Photocopying permitted by license only (C) Berg 2012 Printed in the UK 
evolved a new mode of interior design for the island that allowed for the articulation of different narratives, although these narratives were not progressive in the modernist sense - Bawa simply re-arranged what was already there. The interior of Bawa's home is both atavistic and inauthentic. Finally, the postmodern traits apparent in Bawa's home were used as a resource by his peer group to "think" the South Asian, postcolonial domestic interior and to reconfigure the space of home as it is, rather than making it anew.

KEYWORDS: Geoffrey Bawa, bricolage, Claude Lévi-Strauss, interior design, colonialism, modernity, Ceylon, Sri Lanka

\section{Introduction}

This article discusses the placement of a variety of objects within the domestic space of South Asia in the postcolonial period. It suggests that, instead of following traditional patterns of furnishing, the everyday practices discussed in this article (within the specific historical and political conditions after independence) can be viewed as complex attempts to formulate a space for the development of postcolonial identities. It is argued, however, that these were not progressive attempts in the modernist sense but inventive displacements or rearrangements that suggested an alternative imaginary.

Adopting a case study approach, this article examines the arrangements of furnishings and art objects in the Colombo home of the Sri Lankan architect, Geoffrey Bawa. Both during the latter part of his career and since his death in 2003 , he is regarded as one of the most influential architects of contemporary South Asia. The interior of his own house, acquired and enlarged by stages, and remodeled and furnished by the architect in the years after 1958 (Robson 2002: 232-37), is discussed in relation to the intellectual technique of "bricolage." This term conceptualizes the domestic interior as the purposeful structuring of interior space through the arrangement of objects, thereby making that space meaningful (Taylor and Preston 2002: 173).

This article assesses the meanings invested in the arrangements of objects located in Bawa's house at the present time. Visual records of the interiors of his house in 33rd Lane, Colombo indicate that Bawa experimented with various schemes for interior design before arriving at the one that is now displayed at his house (given the tropical climate, one extraordinary and early image shows a reception room furnished with a number of tapestry-upholstered Queen Anne-style armchairs, in the manner of an article in Country Life, one of the many journals on architecture and interior design to which Bawa subscribed). ${ }^{1}$ Since his death in 2003, a trust has been formed to oversee Bawa's legacy and archive. It now manages 
his house in 33rd Lane (where the Bawa Trust is located) and also his landscape garden at Lunuganga near Bentota. Consequently, the arrangement of objects in the house has become fixed and unchanging, presenting a museum-like tableau of the architect's final furnishing arrangements and thus eliminating any sense of the interior as a dynamic and changing environment.

\section{Previous Literature and the Theoretical Framework}

Much has been written about Bawa's professional output. Previous research by architects and architectural historians has presented mostly descriptive chronologies of his buildings and landscapes (Brawne 1978; Taylor 1986, rev. ed. 1995; Robson 2002, 2007). Another strand of scholarship has discussed Bawa's work in more critically informed terms and located his output in relation to the development of a "critical vernacular" or "critical regionalism" during the 1960s in South Asia (Buchanan 1983; Perera 1999; Jazeel 2007).

In fact, Bawa's architectural projects, both domestic and public, have been quite widely discussed by critics, commentators, and historians. However, the majority of scholars tend to pass over or just briefly describe Bawa's development of a distinctive style of interior design or decoration that attempted to combine modernist and antiquarian objects with local South Asian idioms. The relative neglect in the architectural literature of this activity stems from a seldom articulated but nonetheless powerful assumption that the making of buildings is a masculine activity while the decoration of the interiors of those buildings is more associated with the feminine. Such prejudice can be traced back to the origins of Western modernism and, for example, the criticism, by leading modernist architects, of the retention of "decorative" elements within the interiors designed by the Austrian architect Josef Frank at the Weissenhof exhibition in 1928. In addition, the word bricolage has been used before in previous discussions of Bawa's domestic interiors. However, if it is mentioned at all in relation to his experiments with interior decoration, it has been used as a shorthand term to indicate the superficial, visual effect of mixing different elements within a room and is seldom further discussed.

This article, however, uses the term in a more profound sense. It deploys it in the sense of a "cognitive tool" or intellectual process, a process that plays with the different meanings invested in objects and the new "readings" resulting from those combinations of objects that are rendered by that process. This conceptualization as used in the present article provides a framework that enables us to interpret how architects and designers might, in the words of Tzonis and Lefaivre, express the cultural complexities of a newly independent society (2001: 14); how cultural producers such as Bawa, in the period after independence and using domestic material culture, negotiated between a purportedly Western modernity, an uncomplex indigenism, and the material and cultural vestiges of colonization. 


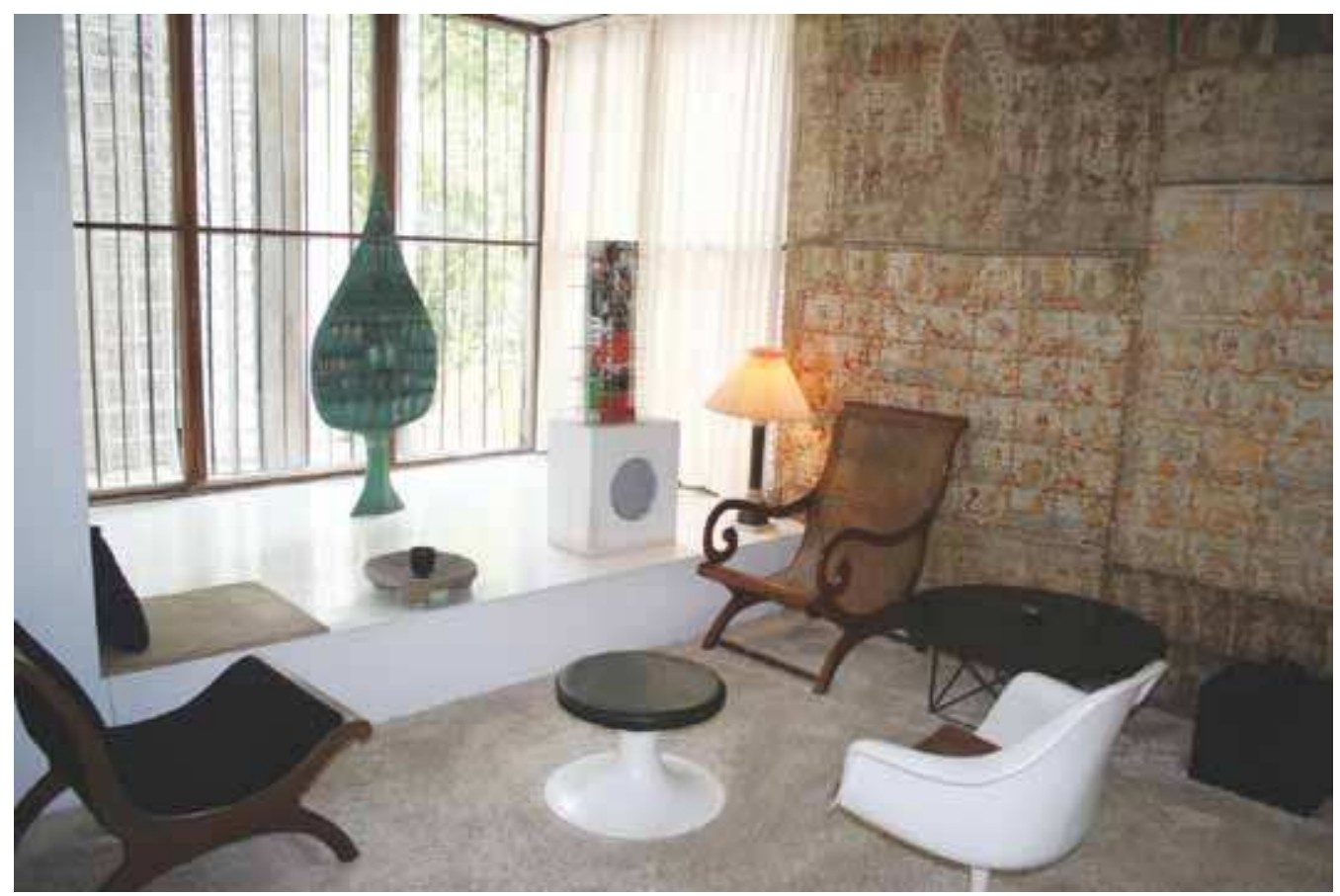

Figure 1

First-floor reception room in Geoffrey Bawa's 33 ${ }^{\text {rd }}$ Lane house, with Knoll-style "tulip" chair, Porset/Barragan-style low chair, nineteenth-century Ceylonese armchair, bo-tree sculpture, and "House of Cards." Photograph by the author.

The article focuses on the architect's own house at number 11, $33^{\text {rd }}$ Lane, Colombo and it approaches this subject by appropriating the term bricolage, which has been used previously in cultural analysis (Figure 1). Initially, the French anthropologist, Claude LéviStrauss, used this term to describe thinking that creates myths and expresses itself with a mixed but limited repertoire of linguistic oddments. ${ }^{2}$ As the cultural theorist David Macey has suggested, "its themes are a subset of a wider culture and already have their own meaning, but they can be arranged in new combinations and contexts" (Macey 2001: 52). More recently, other cultural theorists have widened the application of this term to explain activities other than language and extended its usage to interpret how people use objects and clothing, for example, to express their identity. As design historian, Judy Attfield, has written: "Bricolage is used by anthropologists to describe the process used by particular groups to 'think' their world in a material logic of their own by means of improvisation and appropriating commodities inappropriately" (Attfield 2000: 209). Furthermore, it has recently been suggested that the "postmodern use of citation, [and] the amalgamation of different references in the creation of a postmodern ... aesthetic" owes much to the writings of Lévi-Strauss (Buchli 2011: 113). 
To date, no sustained or critically informed attempt has been made to assess the domestic spaces that the architect designed as meaningful "artifacts" that offered a viable and local alternative to prevailing Western models. By conceptualizing Bawa's own domestic space using this framework, I suggest that the interior of his home became a location to "think" a new way of living that did not simply mimic the colonial interior but neither did it completely remake it. Instead, Bawa reworked an eclectic series of elements in his home, the chief effect of which was to invoke nostalgia for the colonial/feudal past but also to create a space that was "out of time" (Pieris 2007: 151).

Unlike his near contemporary, the Indian architect Charles Correa, Bawa was reticent to theorize his own work and was apolitical in outlook. Furthermore, according to architecture critic Peter Buchanan, Bawa was also designing mostly for an "unabashedly hedonistic contemporary lifestyle" (1983: 16). This article does not propose that Bawa set out consciously to imbue his own domestic interiors with political meaning through their arrangement or organization. These interiors took their present (and now fossilized) form after a process of experimentation and evolved in an organic manner over a period of years. What is interesting about the interior spaces of his home is how they evidence the materialization and negotiation of abstract and problematic concepts around modernity, the colonial past, and local contemporary artistic practice on the island. Rather, this article interprets his domestic space through a close analysis of the meanings immanent in the contents and arrangement of his home and through the location of his domestic interior in its broader political, design historical, and cultural context.

\section{Bawa and "Critical Regionalism"}

Prior scholarship has located Bawa's buildings within a "regional modernism" or "critical regionalism" that was current in post-1950s South Asia. Architectural commentators on this region have noted that Bawa's architecture marked a shift away from the so-called "tropical modern" architecture, which had evolved in the formerly colonized territories during the period immediately before and after the Second World War (Jayawardene 1986: 47-67; Perera 1999: 144-8). Architects who adopted the tenets of "tropical modern" architecture attempted to introduce the underlying principles of Euro-American modernism to colonized or newly independent territories (Le Roux 2004: 337-54). This was an attempt to translate a set of ideas and forms that had developed in the West, applying them rationally and scientifically in a radically different context. The term "tropical modern" implied continuation of the colonial project in the years just before and after independence and applied especially in West Africa, where a number of European architects were practicing in the 1950s and 1960s (Le Roux 2004). 
However, in South Asia, local conditions and climate challenged the approaches and rationale of the "tropical modern" and a number of architects, including Bawa, began to evolve a different way of building. This new approach has been described by Peter Buchanan, Nihal Perera, Alexander Tzonis, Liane Lefaivre, and others as the development of a "critical regionalism" or "critical vernacular." As one commentator has suggested, "critical vernacular" was "a result of a consciousness of the inappropriateness of colonial and modern architecture of the West in a culturally different, extra-European, post-colonial" situation (Perera 1999: 146). Buchanan was among the first to characterize this new movement and he defined this vernacularism or regionalism as "the self-conscious continuation or reattainment of formal symbolic identity" in architecture. He continued that, "unlike Postmodernism, Regionalism can be no mere syncretism ... instead it must be a genuine hybrid, a totally new configuration which may include a remembrance of the past, but transformed or framed in terms of its significance for today" (Buchanan 1983: 15-16). Although this quotation refers to the practice of architecture, it is this selective interplay between remembrance of the past and the present through the bringing together and placement of diverse domestic objects that this article addresses.

\section{Bawa, "Functioning Decoration," and Interior Design}

In a manner similar to the American postwar modernist designers, Ray and Charles Eames, Bawa evolved a process of furnishing his rooms with "carefully composed arrangements of disparate objects" (Kirkham 1995: 164). The design historian Pat Kirkham has discussed the Eameses' use of "functioning decoration," as the latter described such interior arrangements, and how "the aesthetic value was one of addition, juxtaposition, composition, changing scales and 'extra-cultural surprise'” (1995: 164). As Kirkham argues, the Eameses "altered the aesthetic ground rules of modernism"; functionalism had been the predominant concept in architectural and design discourse since the 1920s and "decoration" (of the object or the interior) was regarded as a pejorative term in modern architectural circles (1995: 167). The Eameses' interior decoration drew on a range of sources relating to "design, representation and collecting." As a number of design historians have argued, the use of items from "other" cultures and periods of history to embellish interiors has a long history in the West and as Kirkham writes: "the use of antiques and objets d'art in interior design was a well-established element of Western culture by the middle of the twentieth century" (1995: 168).

The Eameses collected hand-crafted and vernacular objects from different cultures (Mexican, Native American, Indian, Chinese) that signified their "cosmopolitanism and culture" (Kirkham 1995: 169). Bawa's collecting, while superficially similar, differed in an important respect from that of the Eameses. Whereas they valued the vernacular, the hand-worked, and skillfully made, through his appropriation 
of modern design (in the form of Eero Saarinen's "tulip" chair, for example) Bawa also indicated his "cosmopolitanism and culture" but in a South Asian, postcolonial context. In addition, the modern design he appropriated was not simply acquired and assimilated into his interiors unaltered from the West. Due to a period of import controls imposed by the government in Sri Lanka in the early 1960s, Bawa, of necessity, commissioned local craftsmen on the island to replicate these objects, using materials and processes that were available locally (de Silva 1981: 535).

The design historians, Michael Snodin and John Styles, have discussed how European manufacturers in early modern Europe copied desirable but technically unreproducible objects (e.g. lacquerware) from materials that were available in Europe (2001: 133). The consumers who craved these foreign goods wished to acquire a version of the object and/or material for their interiors; to make a connection with the widening world of commerce and to connote their cosmopolitanism and culture. In a related manner, through the process of commissioning copies of modern furniture such as Saarinen's "tulip" chairs or the Eameses' low table from local makers, Bawa was following a pattern that had been established since European colonizers of Ceylon (especially the Dutch and British) had first commissioned local makers to replicate the furniture of their homeland for their own use on the island. Through this process of appropriation, reworking and local manufacture, these Western modern forms of furniture were modified, "Asianized," and assimilated into a new space within postcolonial South Asia. Characterizing Bawa's contribution to the development of a distinctive and South Asian architecture, Nihal Perera has written:

Critical vernacularists [such as Bawa] both cater to the [local] society and transform it ... learning from the past, the locals and distant cultures and displacing East-West, local-global and modern-traditional binaries, [they] have produced "third spaces" for the creation and expression of local modernities. (2010: 77)

Writing in 1983, specifically about Bawa's arrangement of objects in his domestic interiors, Buchanan suggests that "instead of abstracting, he intensifies the impact of elements collected from the past or made by local craftsmen, by deploying them with a Modernist sensibility into a sumptuous scenographic setting" (1983: 16). Buchanan refers in this quotation to Bawa's juxtaposition of "antique" objects and contemporary ones, their arrangement in a theatrical manner, and their perception by visitors to the house, not in the same sense as an architect might visualize them (as part of a ground plan of a building) but as a drawing or painting in perspective and as someone walking through the house would experience them. Bawa's bricolage of domestic objects also invoked personal memory 
and created a space where different, postcolonial South Asian cultural identities could be "tried on," as it were, through the groupings of local, colonial antique furniture, Western modernist items, and contemporary Sri Lankan art works.

\section{Object Categories within Bawa's House}

In the following paragraphs, the objects in Bawa's house are discussed under separate categories to highlight the architect's aesthetic concerns and collecting interests. However, a visitor to the house does not experience the interior spaces of $33^{\text {rd }}$ Lane in this way. David Robson, Bawa's most recent biographer, offers a verbal picture of the impressions gained by a visitor moving through these interior spaces. When one enters the house from the street, the visitor is confronted by

a darkened car port where a pair of beautifully polished cars sit forever on their chocks ... A long white corridor draws you past a set of doors decorated by Donald Friend towards a light well ... In the main part of the house is an evocation of a lost world of verandahs and courtyards, assembled from a rich collection of traditional devices and plundered artefacts, the tower that Bawa created above the car port is nothing less than the reworking of Le Corbusier's Maison Citrohan ... Architectures ancient and modern, Asian and European co-exist as complementary parts of the same whole ... (Robson 2002: 232)

In the tower is located the first-floor reception room furnished in a similar manner to the other rooms in the house with colonial-era furniture from the island, nineteenth-century Asian textiles, contemporary sculpture, copies of International-Style chairs and low, wooden chairs designed by Bawa's office.

\section{The Colonial Antique}

Bawa's home includes a number of "antique" objects, especially furniture produced in Ceylon during the Dutch and British periods of colonization. Bawa's collecting of antique objects (or inclusion of inherited family pieces) can be interpreted as a marker of his modernity through the integration of the past with the present. As Jon Stobart and Ilja van Damme have suggested in relation to the early modern European context, collecting and displaying antiques was "a means of integrating the (distant) past with the present and marking progress between the two"; in addition, "collecting antiques marked the taste and discernment of the owner, the goods themselves being seen as reservoirs of cultural and economic capital" (Stobart and van Damme 2010: intro.). There had been a growing awareness and appreciation of the qualities of antique furniture in Ceylon since the middle decades of the nineteenth century (Jones 2010: 123-5). By 
the turn of the twentieth century, Colombo Museum had begun to acquire a number of items of Dutch colonial period furniture (rather than furniture made during the British period of colonization) and private collections (again of Dutch period furniture) were being formed on the island. ${ }^{3}$ In fact, the first item of furniture encountered when one enters the property and proceeds into the entrance corridor is a carved ebony and cane-upholstered sofa following an English model but locally made in the mid-nineteenth century.

Other examples of locally made, antique colonial period furniture are also found throughout the property. These objects include a Dutch-period (eighteenth century), serpentine-fronted chest made of the rarest timber found on the island, calamanderwood. In addition, a number of locally made, eighteenth- and nineteenth-century almirahs or cupboards, both full size and miniature versions, are also located in different rooms in the house (Figure 2). Other items

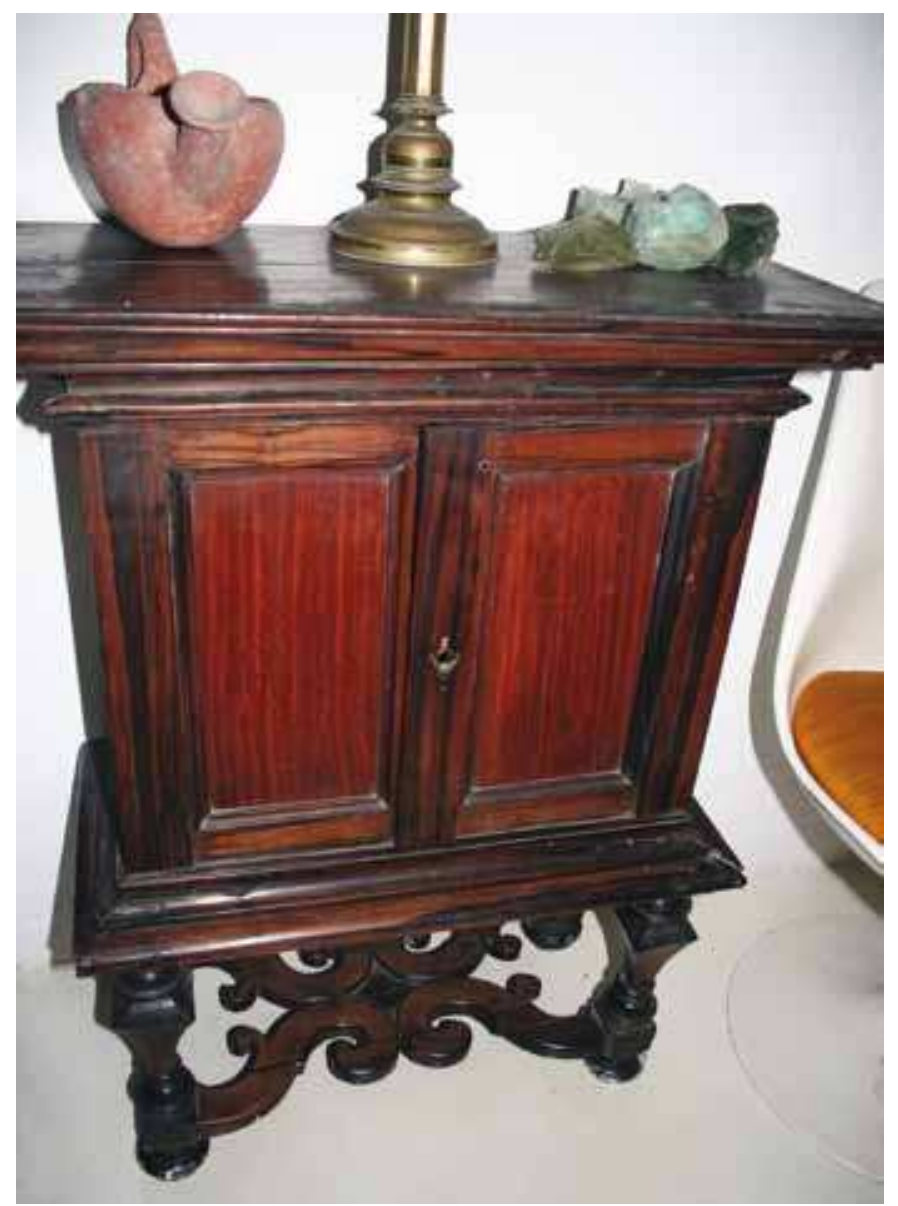

Figure 2

Miniature calamander and satinwood almirah (cupboard). Dutch patronage, eighteenth century, Ceylon. Photograph by the author. 
of antique furniture include storage chests, or pettagama, manufactured during both the Dutch and British periods of colonization of Ceylon; several eighteenth-century chairs made in Sri Lanka for Dutch patrons are also located in a number of rooms of the house.

Bawa had shown an early appreciation of antique objects during his time as an undergraduate at Cambridge University. However, in addition, he traced his ancestry to a culturally significant ethnic group in Sri Lanka, the so-called Burghers, who were descended from unions between members of the Sinhala and Tamil populations and Dutch colonizers of the island (Robson 2002: 15-19). The antique Dutch-era colonial items located in various rooms in Bawa's home connoted, in addition to his cultural (and economic) capital, a deeper connection to his roots in the island, the origins of who he was and a material link to the history from which he had sprung.

\section{The Modernist Machine}

Due to the restricted plot of land with which Bawa was working in the planning of his house, he combined garage space and an entrance hall into one area. Although cars were rarely included as part of the interior decoration of a Sri Lankan room, in fact most usually housed in a separate space from the domestic, Bawa's vintage Rolls-Royce (manufactured in 1933) must also be considered as a feature of the furnishings of his home given its position of prominence at the entrance to the property. As the architectural commentator Lynne Bryant wrote after visiting the $33^{\text {rd }}$ Lane property:

the quiet drama of the [entrance] corridor is interrupted by the lavish spectacle of Bawa's ivory and black Rolls-Royce. This magnificent machine ... - an artwork in its own right - has been treated with the familiarity of a favourite chair or sculpture. The garage occupies the same space as the entrance lobby, [and thereby becomes] a sculpture gallery as much as a car port. (Bryant 1983: 57)

Bawa had been interested since his childhood in mechanical things and his collection of a vintage Rolls-Royce and a Mercedes-Benz indicates his affinity with well-engineered objects. The two cars combine aesthetic beauty and a high level of mechanical sophistication. ${ }^{4}$ They also create extra cultural surprise as one does not normally encounter a car when one enters the interior of a house. The usual associative value attached to cars is that they function out of doors; to come across one inside a home momentarily confounds our expectations.

\section{International Modern Furniture and Postwar Design}

Another significant category of object located in different rooms in the $33^{\text {rd }}$ Lane property comprises furniture and other items in the International Style or postwar modern style of the 1950s and 1960s. 
Through his choice of these objects, Bawa indicated his cosmopolitanism and informed understanding of Euro-American modernism. One of the most prominent examples of this group of objects is a number of the Finnish-American designer Eero Saarinen's plastic "tulip chair," first produced for Knoll in 1956 (Figure 3). It is unlikely that these chairs, located in a number of rooms of Bawa's house, were imported into the island. Given the idiosyncrasies of their construction, it is most probable that they are reproductions made in Sri Lanka to circumvent import restrictions imposed by the government of the island during the 1960s. Bawa kept abreast of contemporary architectural developments in the West following his training at the Architectural Association in London - as the copious collections of architectural books and journals, presently located at the $33^{\text {rd }}$ Lane property, testify. He was inspired by developments in modern architecture and design in the USA and Mexico.

By way of indicating this interest, a collection of texts piled up on an occasional table in one of the ground-floor rooms of the house comprises the following titles: Mid-century Architecture in America (1961); Motels (1960); Built in the USA: Post-war architecture (1952); Architectural Follies in America (1960); Mexico's Modern

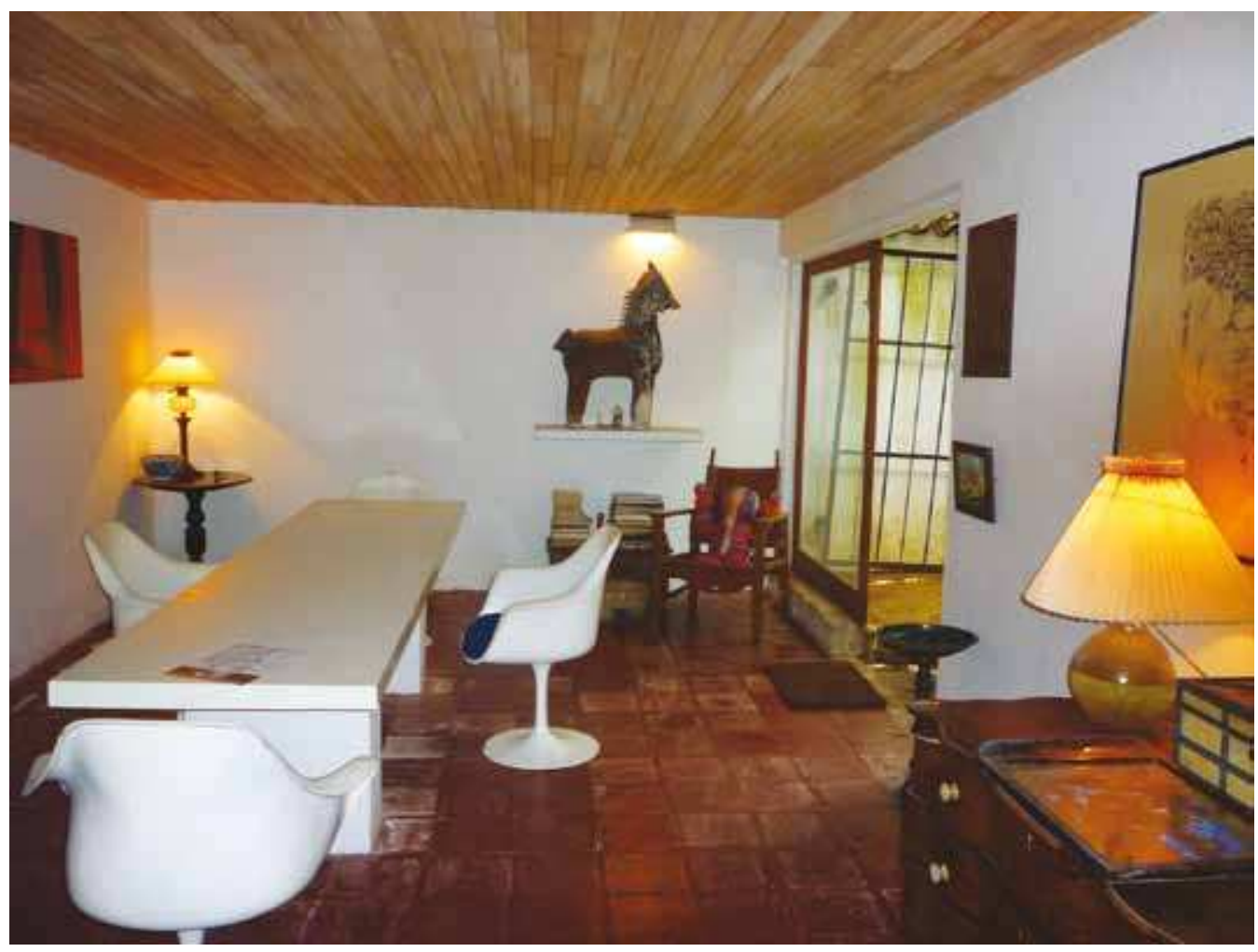

Figure 3

Dining room with Knoll-style "tulip" chairs. Photograph by the author. 
Architecture (1960). There is no way of establishing whether Bawa selected and arranged these texts, although, given the museum-like sclerosis of the contents of his house since he died in 2003, this is most probable. Bawa had also spent five months on a "leadership scholarship" in the United States in 1959 (Robson 2002: 55), when he would have had opportunities to visit key modernist buildings and study up-to-the-minute developments. This period of time spent in the United States provided him with opportunities to familiarize himself with the architecture and design of the American west coast, and Mexico, and also the work of Ray and Charles Eames and Eero Saarinen, as well as that of other architects. ${ }^{5}$ Furthermore, an early architectural partner of Bawa, Valentine Gunasekera, had worked with Eero Saarinen in the United States (Robson 2002: 56).

Other groupings of postwar modernist design are also located in different rooms of his house. These include, for example, a few so-called "butterfly" chairs created in the early 1950s and used in many modern interiors of that time. The "original" "butterfly" chair was designed by Bonet, Kurchan, and Ferrari-Hardoy for Knoll, but these chairs were widely plagiarized and reproduced without license in contemporary interiors throughout the world (Jackson 1992: 104). Bawa's copies were simply part of that unauthorized global appropriation.

In addition to his interest in Knoll's "tulip" chair and the "butterfly" chair as forms of furniture, Bawa's interior decoration scheme for the first-floor reception room of his house is also most probably inspired by watercolor renderings for the Knoll Planning Unit by designers such as Eszter Haraszty, made between 1953 and 1955, and photographs reproduced in contemporary journals of these designs (Eidelberg 2001: 222-3). Bawa was clearly influenced by the way that Knoll's designers, such as Haraszty, treated interior space. The following description of her characteristic treatment of a room could equally be applied to the manner in which Bawa configured his own reception room:

The rooms are open, large spaces, divided into separate areas by rugs and by the arrangement of the furniture in geometric islands, either parallel to the wall or at a forty-five degree angle to it. (Eidelberg 2001: 223)

Even though Bawa's reception room is not a large space and, in fact, is slightly cramped, the furnishings have been arranged to "create a modern sense of flowing space and freedom of movement" (Eidelberg 2001: 223). One of the most widely published interiors designed by Haraszty at the time was the Knoll studio in Paris. Although Bawa did not simply copy such an interior, it is worth quoting in full a description of Knoll's Paris studio as a number of underlying features is also found in Bawa's reception room: 
Here in a small apartment on the top floor of an old building, Haraszty blended old and new. She used some Knoll furniture: Bonet, Kurchan and Ferrari-Hardoy Butterfly chairs and Saarinen dining chairs. These were supplemented with two seventeenth-century chandeliers and a turn of the century Thonet chaise [bought at a flea market]. The extravagant curving lines of the chaise make it the most interesting form in the room. (Eidelberg 2001: 223)

Bawa's inclusion in his reception room of old objects and new (including a replica of Knoll's "tulip" chair) as well as a Thonet bentwood chair, not dissimilar from the one described above, and its placement (as in Haraszty's rendering) where its curving form would be most appreciated by a visitor entering the room, very closely replicates the chief features of Knoll's Paris studio (Figure 4).

Bawa also acquired examples of the fashionable inflatable plastic seating of the late 1960s, including a clear plastic armchair designed and manufactured (from 1969) by the company Quasar-France (Byars 1994: 457). In addition, he acquired a number of pieces of modernist Scandinavian glassware, including several imposing colored and transparent mold-blown, cut-off, cut-glass candlesticks,

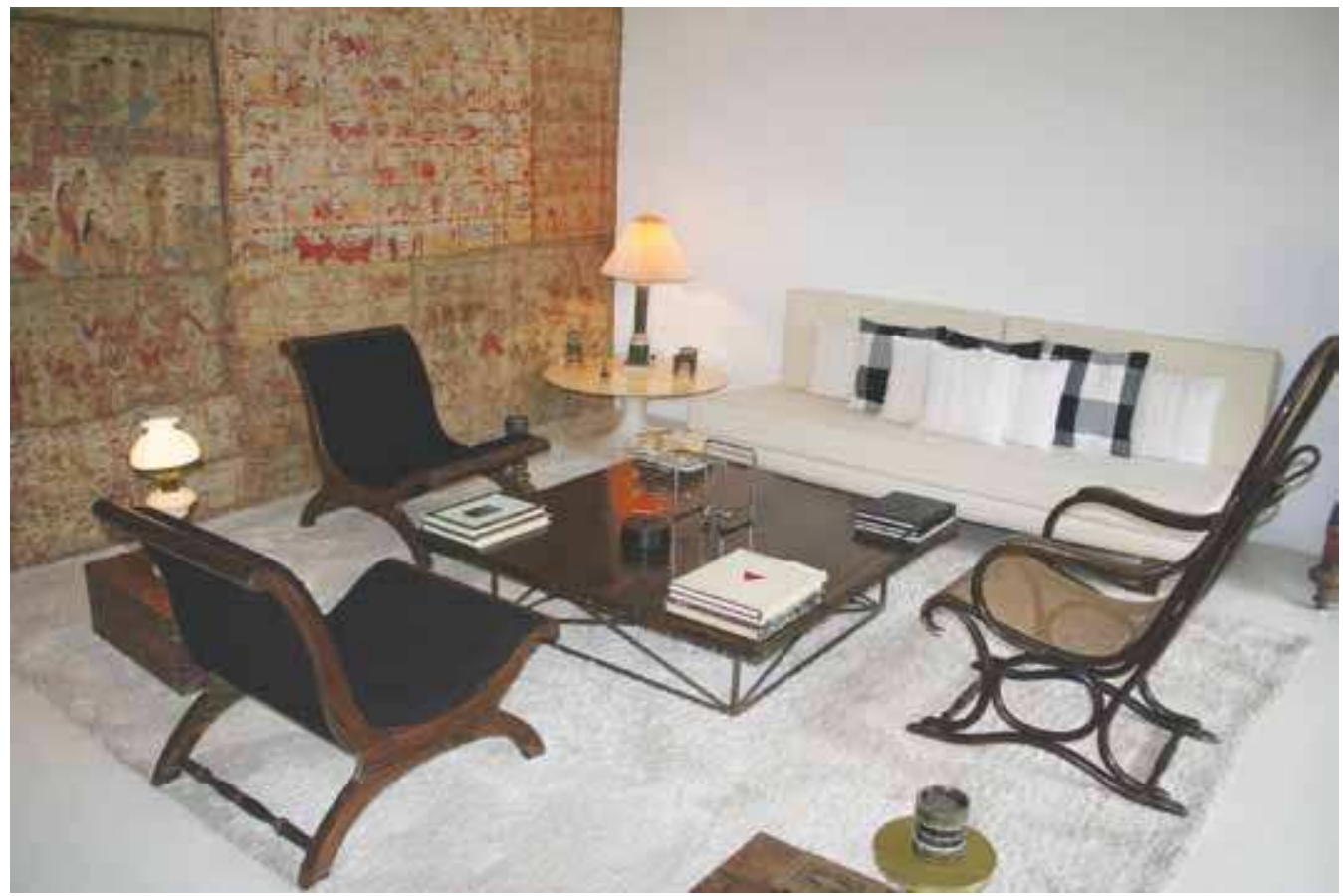

Figure 4

First-floor reception room with Thonet bentwood chair and Porset/Barragan-style low chairs. Photograph by the author. 


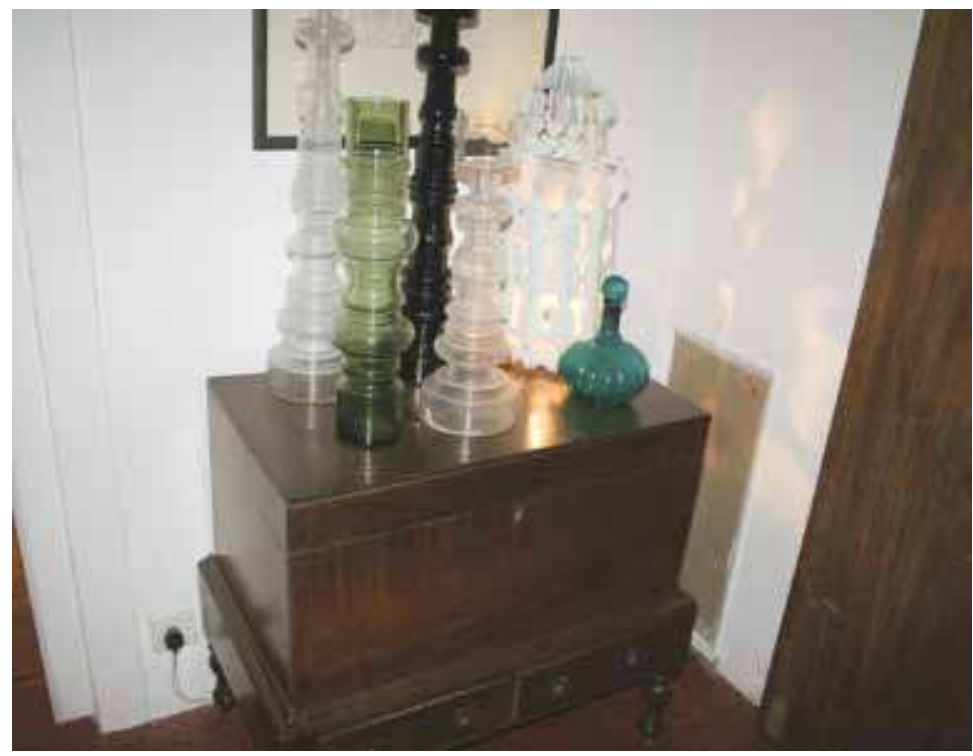

Figure 5

Scandinavian glass candlesticks (1960s-1970s) on nineteenth-century Ceylonese pettagama (storage chest). Photograph by the author.

some of which were designed by the Finnish designer, Oiva Toikka and produced at the Nuutajarvi Glassworks in Finland between 1964 and 1973 (Aav et al. 2010: 135) (Figure 5). The influence of Scandinavian architecture and design was widely prevalent in the 1950s and 1960s in Europe and America; in addition, Sri Lankan architects and designers had a particular and direct connection to Scandinavian modern design (through Bawa's one-time partner, the Dane, Ulrik Plesner, and because, as a result of his influence, a number of young Sri Lankan architects trained in Copenhagen in the late 1960s, where they were taught by Poul Kjaerholm and others) (Jones 2011: 19-20).

\section{Bawa, Latin American Modernity, and the Vernacular}

Little has been written specifically about the influence of Mexican modernism and the work of architects such as Luis Barragan (19021988) on Bawa's output. ${ }^{6}$ It is most probable that Bawa would have become aware of Barragan's work (and general developments in Mexico) during the latter's visits to America. In a similar manner to Bawa, Barragan endeavored in his work to negotiate between Western modernism and the vernacular (of Mexico). Barragan was of a generation prior to Bawa and had made a name for himself in architecture with the design, among other projects, of his own house at Jardines del Pedregal, Tacubaya, Mexico, completed in 1948 (Hitchcock 1955: 45-6, 182-5). The biographies of the two architects were similar also in that Barragan had come into 
architecture from a previous career (as an engineer) and as HenryRussell Hitchcock wrote with no training as an architect 'indeed with no technical training at all' (1955: 45).

Barragan collaborated on many of his architectural projects with the influential Cuban-born designer Clara Porset (1895-1981), who lived for most of her life in Mexico as a political exile (Estrada 2006). ${ }^{7}$ She and her husband, Xavier Guerrero, were part of a large group of designers, artists, and architects who were redefining modern Mexican design during the middle decades of the twentieth century. As a number of designers were attempting to do, both in Europe and the Americas during the 1920s and 1930s, she looked to traditional, vernacular forms (found in Mexico) and refined these to produce objects that were modern but also of their place, making reference to previous histories. One of her most influential chair designs was the simply named "butaca" or "butaque" (Sp. armchair), a modern reworking of a vernacular Mexican chair, produced during the 1940s and used in a number of Barragan's buildings.

A type of low chair, wooden-framed and caned, with a raked back and supported on down-curved legs in a flattened $U$ form, its back legs joined by a turned stretcher, was used widely in many of Bawa's buildings, including his own house and, on a larger scale, in the reception areas and bedrooms at Bawa's Bentota Beach Hotel (completed 1970). The design for this chair, which David Robson has attributed to Bawa's office, bears a striking similarity to a low, leather upholstered chair (although with arm rests) depicted in a photograph of a reception room in Luis Barragan's own house (completed 1948) (Hitchcock 1955: 185; Robson 2007: 68). In the same photograph, a sofa of similar form is also depicted. These items of furniture (the "butaca" or "butaque" chair, although with arms, and sofa) were both designed by Clara Porset for Barragan. It is most probable that Bawa appropriated this design and slightly modified it (doing away with the arm rests), as he had previously done with other items of furniture. Porset's chair is upholstered with brown leather, a material used on seventeenth- and eighteenth-century Iberian and Spanish colonial seating, and the original model would most probably have been an antique Spanish colonial chair used in Mexico.

Bawa's version, created in the late 1960s and used for the first time in the Bentota Beach Hotel, is upholstered in cane, which is more suited to a tropical climate. In addition, and perhaps why the form was originally adopted by the architect, Bawa's version references a very similar British colonial low armchair that was produced during the nineteenth century by local makers in Ceylon for both British residents and the Ceylonese elite. ${ }^{8}$ It was a type of chair that would have been familiar to him. In fact, a nineteenthcentury version of this armchair is located at the present time in the first-floor reception room of Bawa's house (facing a "butaca"-style low chair), and an ebony chair of this type was owned by Geoffrey Bawa's brother and is still located in the house in which he lived (at 
"Brief," Kalawala, Bentota). The main features of this group of low, cane-upholstered armchairs are their raked backs, over-scrolled arm rests, and inverted, flattened U-shaped (or "curule") front and back legs, and they present a similar side profile to Porset and Bawa's low chair. ${ }^{9}$

The process of researching an old design, appropriating it, and refining it for use in the contemporary period was exemplified by Scandinavian architects such as Kaare Klint in the 1920s. This model of arriving at a new design solution by studying previous "classic" designs and reworking them most probably derives from the influence of Bawa's earliest architectural partner, Ulrik Plesner, whose stepfather was Kaare Klint. ${ }^{10}$ In addition to the aesthetic appeal of its form, and its functionality, Bawa's low, caned chair also connotes or references a complex network of concepts. These include: the work of an influential, non-Western designer, who blended the modern with the local (in the way Bawa was attempting to do); the form of a British colonial period chair; and a process of design research that could be traced through the English arts and crafts movement and Danish modernism of the first half of the twentieth century.

\section{Local South Asian Artifacts}

Locally produced South Asian objects other than furniture also played an important part in Bawa's interior design schemes. These comprised sculpture, architectural salvage, and textiles. For example, three nineteenth-century baluster-shaped columns of turned South Asian hardwood were used as structural supports for the entrance to the dining room at $33^{\text {rd }}$ Lane. Bawa arranged for the lower part of these, up to around a meter from the floor, to be stained a brown color. This was to create a visual effect for visitors. When they approached the dining room, the brown staining on the columns blended with the color of the polished terracotta floor tiles in that room, making the columns appear, for a moment, in the low light of evening, to almost float unsupported in space. The dining room also housed an imposing, early twentieth-century Sri Lankan terracotta figure of a stylized horse.

One room on the ground floor was fitted with a large white shelf on which is positioned an early twentieth-century Thai cast iron and gold-painted standing figure of the Buddha. An interior pool at the end of the entrance corridor, open to the sky, is framed by three massive, hardwood antique Chettinad columns from Tamil Nadu and an antique painted terracotta horse's head from Chilaw, on the west coast of Sri Lanka. Other Indian and Sri Lankan carved wooden panels and masks are located in different rooms in his house, including a nineteenth-century carved mask of Mahasammatha, most probably produced at Ambalangoda on the south-west coast of the island. One wall of the first-floor reception room is covered with a series of nineteenth-century resist-dyed cotton wall hangings, depicting mythical scenes and most probably from Indonesia. 
Bawa's interest in antique South Asian art objects indicates another characteristic of the bricoleur, that is, as Victor Buchli suggests, "a different concept of time compared to the modernist: one that is retrospective, based on the continuous reworking of received elements of the world" (2011: 113).

\section{Contemporary Sri Lankan Artworks}

A more significant group of objects, however, comprises artworks produced by contemporary Sri Lankan artists or foreign artists working in Sri Lanka during the period after independence. Most of these artists collaborated with Bawa on his architectural commissions and their art works imbue his house with a distinctive and local contemporary ambience. The most prominent Sri Lankan artists represented by their work in the $33^{\text {rd }}$ Lane property are Ismeth Raheem, Ena de Silva, and Laki Senanayake (Robson 2007: 122-5, 177-9, 182-7). There are also works by the Australian artist Donald Friend, who lived in Sri Lanka between 1957 and 1962 (Art of Donald Friend 2004). Ena de Silva's work is immediately apparent on entering Bawa's house, as the wall to the left of the entrance porch is covered with an imposing, brightly colored resist-dyed banner or hanging (1970) depicting a stylized sunburst. One of Ismeth Raheem's major contributions to the Bawa house is the creation of a beaten, gilded aluminum door for the first-floor reception room, which depicts a series of small birds perched on a stylized fountain. When the door is opened, the visitor to this room perceives this object not as a functional part of the room but as an artwork in its own right, and a dissolution of architectural space occurs through its transformation into an object of art. A number of works on paper by the artist, Laki Senanayake, are scattered throughout the house, some depicting the tropical flora or local people of the island. Located in a prominent position in the first-floor reception room is Senanayake's metal sculpture of the bo leaf. Finally, a number of the rooms in Bawa's house are animated by the work of Australian artist, Donald Friend. Friend's works, now sadly removed from the house and replaced by painted replicas, consisted of painted trompe l'oeil door panels depicting colorful, whimsical narrative scenes from the late colonial period on the island. ${ }^{11}$

\section{An Assessment of Bawa's Interior}

It is useful to consider the type of furnishings within the domestic space in which Bawa had spent his formative years. Middle-class domestic furnishing schemes created during the last decades of colonialism in Ceylon, such as those in Bawa's parental home, presented conservative arrangements of hybrid furnishings - locally made but of Western, historical revival-style or in the prevailing style of the West such as the moderne. These types of comfortable but backward-looking domestic interiors might be said to have objectified the colonial relationship between Britain and Ceylon. By this I 
mean that, although the labor and materials were local, the concept and design of the furniture (and the behavior engendered by its form) originated in the homeland of the colonizer. The form of the furniture and the style in which it was executed connoted the material culture of Western Europe. Its placement and use in local homes on the island disciplined the Ceylonese body into Western patterns of social behavior and body posture (Jones 2007: 145-63).

The present article assesses Bawa's carefully arranged combinations of diverse domestic objects as a significant but hitherto overlooked aspect of his overall creative output. In the same way that he treated his landscape garden at Lunuganga, I suggest that Bawa also used his home as a kind of laboratory to experiment with different arrangements of space and objects over time (Jones 2011: 9-24). In fact, the interiors of his home could be regarded as a type of landscape, where vistas were arranged or structured and the various items in the rooms functioned as parts of a metonymic terrain.

I suggest that Bawa used the intellectual technique of bricolage not simply to create a visual effect but also to "'think' his world through a material logic of his own" (Attfield 2000: 209). This was achieved by improvisation, juxtaposition, and the appropriation of different commodities, in an unusual way or one deemed conventionally to be inappropriate (Attfield 2000: 209). I am not proposing here that this was effected by a series of pre-planned acts on Bawa's part but through a gradual process, experimental in nature, and intuitive. Nor does this article seek to position the architect as modernist hero, presenting Bawa as a South Asian "genius." He was affected and influenced by a range of different artistic, architectural, and cultural currents and negotiated between these throughout his career. In other words, to fully understand his experiments in interior design, they need to be situated within a broader design historical, architectural, and political context than hitherto.

For the purposes of clarity, this article has segregated different categories of object, but when one experiences the interior of Bawa's house, these different categories are in a dialogic relationship. Two brief examples will suffice: Ena de Silva's batik "sunburst" textile panel and the Rolls-Royce parked next to it and Laki Senanayake's stylized sculptural representation of a bo leaf and the Eameses' "House of Cards" (Figures 6 and 7).

Although the resist-dye printing technique on cotton was not local to Sri Lanka, Ena de Silva selected a traditional South Asian form and motifs but contemporized them. The form references a ceremonial banner from pre-colonial Ceylon. The main motif is a stylized version of "the Mansion of the Sun," one of the 108 auspicious symbols associated with the foot of the Buddha and found in the mangul-lukunu (Coomaraswamy 1956: 110-11). The motif to the center of the wall hanging comprises four pairs of linked, parrot-like birds. The parrot (giriva) is used extensively in Dravidian art and Coomaraswamy illustrates the linked parrot (giriva puttuva) motif 


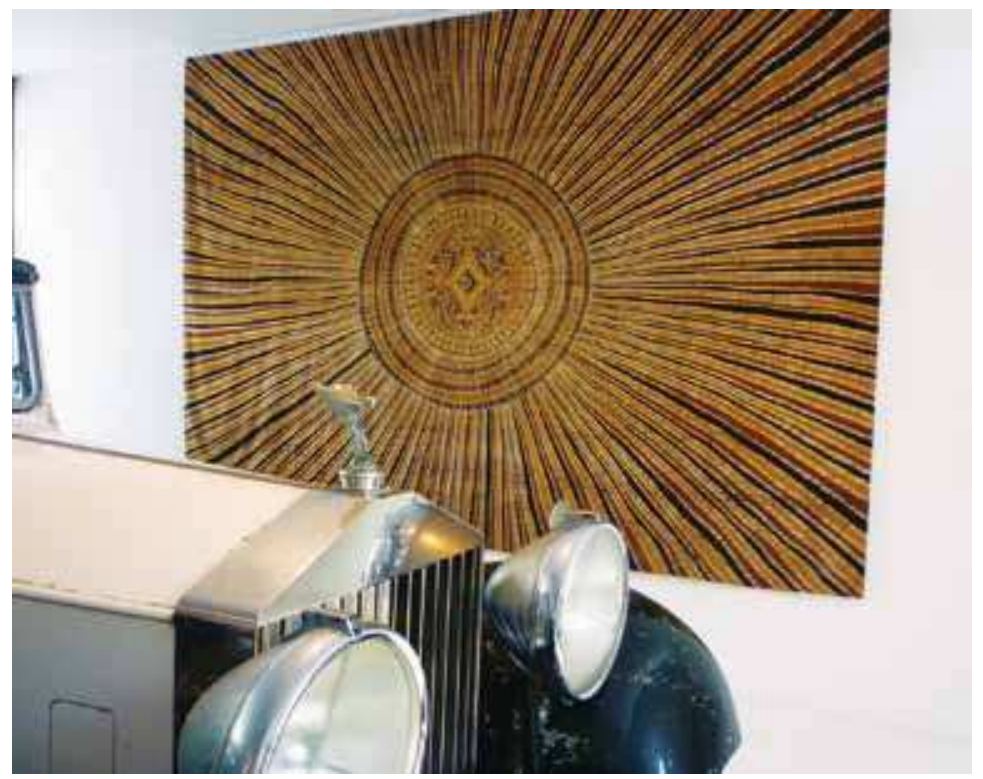

Figure 6

Bawa's vintage Rolls-Royce and Ena de Silva's sunburst banner in the entrance corridor. Photograph by the author.

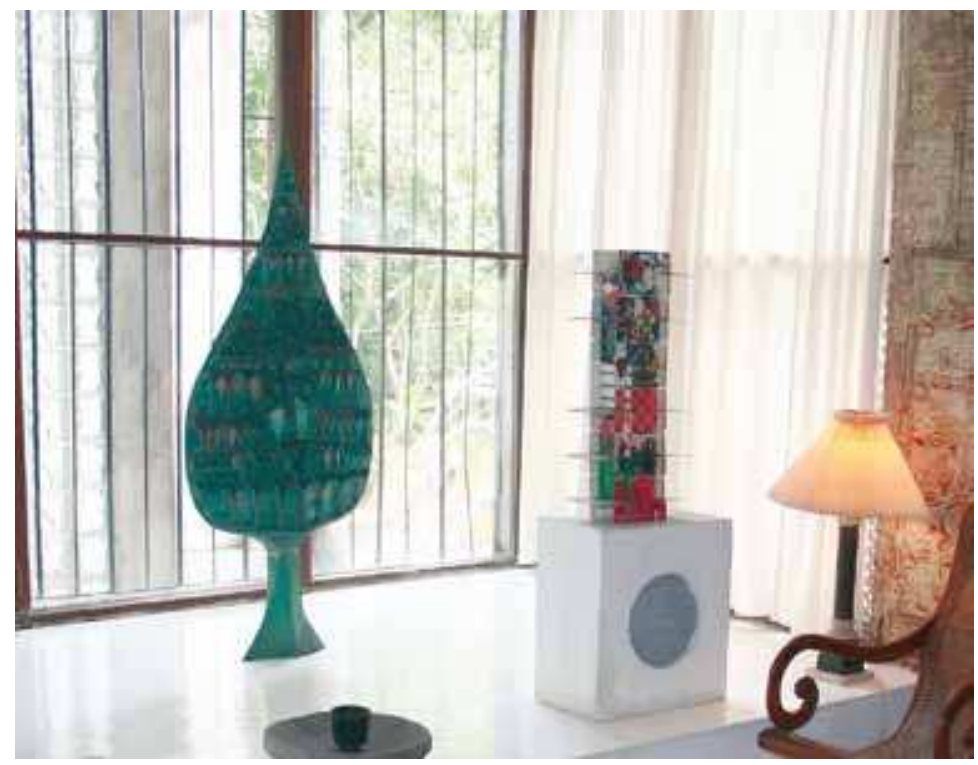

Figure 7

Laki Senanayake's metal bo-tree sculpture and Ray and Charles Eameses' "House of Cards" in the first-floor reception room. Photograph by the author. 
on a piece of carved wood (Coomaraswamy 1956: pl. xxxv). Ena de Silva's textile is juxtaposed with the vintage Rolls-Royce (located a short distance from the wall hanging), which connoted Western privilege, luxury, mechanical prowess, and the aesthetic appeal (and sculptural qualities) of the modern machine. It also connoted, more generally, aspects of the British colonial past (such cars were used for colonial ceremonial occasions) but also qualities of that past surviving into the present.

Through this and other juxtapositions Bawa operated as a "jack of all trades" or bricoleur, ransacking the "ready at hand" to produce a new effect that was, however, inherently anti-modern (Buchli 2011: 113). By juxtaposing a prestigious motor car produced in the colonial metropole with a textile executed by a contemporary Sri Lankan designer, Bawa indicated his acceptance of the world as it is and simply reconfigured it rather than inventing a new one.

Located in a prime spot in the first-floor reception room, Laki Senanayake's stylized metal bo leaf sculpture offered a contemporary interpretation of a key emblem of Buddhist spirituality. As Ananda Coomaraswamy has written, the Gautama Buddha appeared on Earth for the salvation of mankind and attained enlightenment beneath the bo-gaha or bo tree (ficus religiosa) (Coomaraswamy 1956: 274). He continues, the tree became a symbol of the Buddha's victory over earthly desires and stands as a "perpetual symbol in Buddhist art." Senanayake first devised this form for the wellreceived Ceylon Pavilion designed by Bawa for the Osaka World Fair in Japan in 1970 (Robson 2002: 107). The bronze sculpture at Osaka was about 40 feet (12 meters) high. The smaller version of Senanayake's bo leaf sculpture in Bawa's first-floor reception room is located close to and juxtaposed with Ray and Charles Eames's "House of Cards" (1952), a symbol of playful, eclectic (and purportedly Western) modernity (Kirkham 1995: 162; Murphy 1997: 66, 131-2). ${ }^{12}$ In addition, as Joseph Giovannini suggests, "the House of Cards," albeit on a diminutive scale, also addresses the issue of the spatiality of color, how "some colours advance in space and some recede" (1997: 66). Kirkham suggests that "the House of Cards" was a "do-it-yourself 'Eames aesthetic' kit with which people could make their own juxtapositions of images and learn the skills of 'functioning decoration'" (1995: 162).

\section{Conclusion}

It has been argued previously that "objects removed from their larger schemes of meaning take on other meanings as they are redefined within different (often private or local) schemes" (Kirkham 1995: 184). In a related manner to his landscape designs, Bawa's interior design scheme charts a course between slavishly maintaining or reworking the material culture of the colonial period, uncritically adopting the intellectual achievements of Western modernism with its 
taint of colonial subjugation or the willful neglect of this problematic past through the adoption of a narrow indigenism. This negotiation was enabled, it is suggested here, through a process of intellectual bricolage. The meanings invested in all of the objects previously discussed are subsets of wider cultures and already have their own meanings but these are rearranged in new combinations to generate new ways to think.

As Lévi-Strauss suggested, these new ways to think included the assemblage of bits of an existing world into another imaginable one. These new ways to think were, however, non-utopian. Bawa, as bricoleur, did not imagine a "new language or set of material circumstances that would remake the world" (Buchli 2011: 115). His new ways to think the interior were not progressive in the sense of the contributions of architects and designers of the modern movement, for instance. Instead he creatively "re-arranged what was already there" (Buchli 2011: 115).

Although the arrangement and types of furnishings contained within a room may appear to some trivial or of small significance beyond their function and style, it has been argued by Mark Kingwell that the way in which rooms are furnished determines what kind of thoughts are possible there. As he writes, when we organize furniture "we are, in effect, seeking new forms of meaning to create, new ways to think ... how rooms are furnished ... determines in large measure what kind of thoughts are possible there" (2002: 177). He continues, "furniture is an invitation to think, to dream, a beckoning of possible ideas and half-formed notions" (2002: 178).

Bawa perhaps would not have recognized it as such or even articulated it in so many words; nonetheless, it is arguable that the cognitive processes he followed in the arrangement of his domestic space were akin to a process of intellectual bricolage. In The Savage Mind, Lévi-Strauss makes the distinction between the bricoleur and the engineer. The bricoleur is mainly "concerned with some sort of inventive displacement, rather than inventive novelty" (Buchli 2011: 113). By contrast, the engineer makes the world anew.

Through a process of bricolage, Bawa evolved a new mode of interior design for the island that allowed for the articulation of different narratives (that were materialized in the combinations of objects in his house). However, these narratives were not progressive in the modernist sense. By his process of bricolage, Bawa simply rearranged what was already there. This rearrangement suggested an "alternative imaginary world at once out of history and archaic" (Buchli 2011: 115). As a result of his experiments in interior design, the interior of Bawa's house is both atavistic and inauthentic, as well as being removed from time. Finally, the postmodern traits that are apparent in Bawa's interior and that celebrated hybridity became an influential resource for his peer group to "think" the postcolonial domestic interior in Sri Lanka (and South Asia) and to reconfigure the space of home as it is, rather than making it anew. 


\section{Notes}

1. An article by Lynne Bryant on Bawa's house in the Architectural Review of 1983 illustrates a number of rooms with varied furnishing arrangements; these differ from those found in the house at the present time.

2. Claude Lévi-Strauss, The Savage Mind (1962).

3. R.L. Brohier, Furniture of the Dutch Period in Ceylon (1969) discusses the antiquarian interest in Dutch colonial furniture on the island and the formation of early collections.

4. Conversation with Laki Senanayake, August 31, 2011.

5. Throughout his career Bawa also subscribed to a number of architectural journals, including Architecture, published by the American Institute of Architects. He also subscribed to $A A$ Files (Architectural Association, London), RIBA Journal (Royal Institute of British Architects), and MIMAR. Large numbers of back copies of these and other related journals are located in the $33^{\text {rd }}$ Lane property.

6. During a conversation in April 2011, David Robson suggested that Barragan may have been an influence on Bawa and that the design for a type of chair that Bawa used in his own house and also to furnish some of his hotels (including Bentota Beach) may have derived from designs by Barragan. I am grateful for and acknowledge his suggestions.

7. Porset had studied in New York and Paris and in 1934 spent a short time at Black Mountain College, North Carolina, where she was taught by Josef Albers, whose teaching had a lasting effect on her work. She and her husband were political exiles in Mexico and made their careers in that country. In 1940 she won a prize in MOMA's Latin American competition for Organic Design in Home Furnishings.

8. An image of this type of armchair can be found in A. Wright (ed.), Twentieth-century Impressions of Ceylon (London, 1907), p. 222.

9. It is interesting to note that Porset's "butaca"/"butaque" and Bawa's version of it are constructed in different ways. Bawa's version follows a traditional method used in Sri Lanka from the nineteenth century.

10. Other examples of the Bawa office's adaptation and refinement of European furniture forms, both old and new, comprises a version of a "Hepplewhite"-style armchair and side chair used in the guest rooms and public areas of the Kandalama Hotel and a more radical reworking of the form of Arne Jacobsen's tallbacked St Catherine's College chair, depicted in photographs of Bawa's house in the 1980s.

11. Friend's door panels are now in the collection of the Art Gallery of New South Wales, Sydney, Australia.

12. The House of Cards is a "modular constructional toy ... which used a pack of 52 cards ... each with six slots so that one 
could fit into another. On one side of the 'pattern deck' was an assortment of patterns and textures; on the other was a black asterisk" (Kirkham 1995: 162).

\section{References}

Aav, M., Vakkari, S. and Viljanen, E. (eds). 2010. Oiva Toikka: Moments of Ingenuity (exhibition catalog). Helsinki: Designmuseo. Adamson, G., and Pavitt, J. (eds). 2011. Postmodernism: Style and Subversion, 1970-1990. London: V\&A Museum.

The Art of Donald Friend - Ceylon (exhibition catalog). 2004. Colombo: Australian High Commission.

Attfield, J. 2000. Wild Things: The Material Culture of Everyday Life. Oxford: Berg.

Brawne, M. 1978. "Geoffrey Bawa." The Architectural Review, CLXIII(974): 207-21.

Bryant, L. 1983. "ID: House, Colombo, Sri Lanka." The Architectural Review, CLXXIII(1035): 57-60.

Buchanan, P. 1983. "With Due Respect: Regionalism." The Architectural Review, CLXXIII(1035): 15-16.

Buchli, V. 2011. "Bricolage." In G. Adamson and J. Pavitt (eds), Postmodernism: Style and Subversion, 1970-1990. London: V\&A Museum.

Byers, M. (ed.). 1994. The Design Encyclopedia. London: Laurence King.

Coomaraswamy, A.K. 1908, rev. 1956. Medieval Sinhalese Art. Broad Campden and New York: Pantheon Books.

de Silva, K.M. A History of Sri Lanka. 1981. New Delhi: Oxford University Press.

Eidelberg, M. (ed.). 2001. Design 1935-1965: What Modern Was. New York: Harry N. Abrams.

Estrada, G. (ed.). 2006. El Diseno de Clara Porset: Inventado un Mexico Moderno/The Designs of Clara Porset: Creating a Modern Mexico. Mexico City, Mexico: Turner/Museo Franz Mayer.

Giovannini, J. 1997. "The Office of Charles and Ray Eames: The Material Trail." In D. Murphy (ed.), The Work of Charles and Ray Eames: A Legacy of Invention (exhibition catalog). New York: Harry N. Abrams.

Hitchcock, H-R. 1955. Latin American Architecture since 1945. New York: the Museum of Modern Art.

Jackson, L. 1992. The New Look: Design in the Fifties. London: Thames and Hudson.

Jayawardene, S. 1986. "Bawa: A Contribution to Cultural Regeneration." Mimar, 19: 47-67.

Jazeel, T. 2007. "Bawa and Beyond: Reading Sri Lanka's Tropical Modern Architecture." South Asian Journal for Culture, vol. 1: $1-22$.

Jones, R. 2007. Interiors of Empire: Objects, Space and Identity within the Indian Subcontinent, c. 1800-1947. Manchester: Manchester University Press. 
Jones, R. 2010. "'Souvenirs of People Who Have Come and Gone': Second-hand Furnishings and the Anglo-Indian Domestic Interior." In J. Stobart and I. van Damme (eds), Modernity and the Second-hand Trade: European Consumption Cultures, 17001900. London: Palgrave Macmillan.

Jones, R. 2011. "Memory, Modernity and History: The Landscapes of Geoffrey Bawa in Sri Lanka, 1948-1998." Contemporary South Asia, 19(1): 9-24.

Kingwell, M. 2002. "Tables, Chairs and Other Machines for Thinking." In M. Taylor and J. Preston (eds), Intimus: Interior Design Theory Reader. Chichester: Wiley.

Kirkham, P. 1995. Charles and Ray Eames: Designers of the Twentieth Century. Cambridge, MA, and London: MIT Press.

Le Roux, H. 2004. "The Networks of Tropical Architecture." The Journal of Architecture, 8(3): 337-54.

Lévi-Strauss, C. 1962. The Savage Mind. London: Weidenfeld \& Nicholson.

Macey, D. 2001. Dictionary of Critical Theory. London: Penguin Books Ltd.

Murphy, D (ed.). 1997. The Work of Charles and Ray Eames: A Legacy of Invention (exhibition catalog). New York: Harry N. Abrams.

Perera, N. 1999. Decolonizing Ceylon: Colonialism, Nationalism and the Politics of Space in Sri Lanka. Oxford: Oxford University Press.

Perera, N. 2010. "Critical Vernacularism: A Locally Produced Global Difference." Journal of Architectural Education, 63(2): 76-7.

Pieris, A. 2007. Imagining Modernity: The Architecture of Valentine Gunasekera. Colombo: Stamford Lake (Pvt) Ltd. \& Social Scientists' Association.

Robson, D. 2002. Geoffrey Bawa: The Complete Works. London: Thames and Hudson.

Robson, D. 2007. Beyond Bawa: Modern Masterworks from Monsoon Asia. London: Thames and Hudson.

Snodin, M. and Styles, J. (eds). 2001. Design and the Decorative Arts: Britain 1500-1900. London: V\&A Museum.

Stobart, J. and van Damme, I. (eds). 2010. Modernity and the Second-hand Trade: European Consumption Cultures and Practices, 1700-1900. London: Palgrave Macmillan.

Taylor, B. Brace. 1986, rev. ed. 1995. Geoffrey Bawa. Singapore: Concept Media; London: Thames and Hudson.

Taylor, M. and Preston, J. (eds). 2002. Intimus: Interior Design Theory Reader. Chichester: Wiley.

Tzonis, A., Lefaivre, L. and Stangos, B. (eds). 2001. Tropical Architecture: Critical Regionalism in the Age of Globalization. Chichester: Wiley. 